\title{
VAIKUTTAVAAN TÄYDENNYSKOULUTUKSEEN
}

$\mathrm{T}$ ämän lehden teemana on työelämän koulutus ja ammatillinen aikuiskoulutus. Eri kirjoituksissa tarkastellaan erityisesti henkilöstökoulutusta, sen kohteita, toteuttamistapoja ja vaikuttavuuden arviointia.

Työyhteisöjen sisäisen ja ulkopuolisen ammatillisen täydennyskoulutuksen määrä Suomessa on erittäin suuri. Koulutukseen osallistuu joka vuosi noin miljoona suomalaista. Arvioidaan, että 40 prosenttia työväestöstä osallistuu vuosittain henkilöstökoulutukseen.

Koulutusta tarjoavat yli 1000 koulutusorganisaatiota yliopistoista yksityisiin koulutus- ja konsulttiyrityksiin. Esimerkiksi ammatillisilla oppilaitoksilla on yli 500 aikuiskoulutusta antavaa yksikköä. Koulutuksen tarjonta on kestoltaan muutamasta päivästä monivuotisiin kehittämisohjelmiin.

Eri tyyppisten aikuiskoulutuspalvelujen määrällisten tarpeiden arvioidaan vielä olennaisesti kasvavan monilla aloilla. Kuitenkin taloudellisen laman aikana on kilpailu eri koulutusorganisaatioiden välillä kasvanut olennaisesti. Useimmat koulutusta tarjoavat organisaatiot ovat joutuneet vähentämään toimintaansa ja henkilökuntansa määrää. Myös monet työyhteisöt ovat vähentäneet koulutuksen suunnitteluhenkilöstöään.

K oulutusorganisaatioiden välinen kilpailu asiakkaista pakottaa eri yksiköt toisaalta kehittämään laatuaan ja toisaalta miettimään omia vahvuuksiaan. Asiakkaiden kannalta tilanne on johtanut varmasti hintojen tarkistuksen ohella parantuneeseen palveluun.

Koulutusorganisaatioiden kilpailu asiakkaista kasvaa vielä lähivuosina, kun yhä uusia tahoja ilmaantuu tarjoamaan palvelujaan. Esimerkiksi kansalais- ja työväenopistot ovat ottamassa kasvamassa määrin - osittain taloudellisen tilanteensa pakottamine - tarjontaansa ammatillisesti pätevöittäviä kursseja. Yksityiset, aikaisemmin liike elämää palvelleet koulutus- ja konsulttiyritykset ovat taas työntymässä entistä voimallisem- min kehittämään valtion ja kuntien henkilöstöä. Koulutusorganisaatioiden taloudellinen tilanne on johtanut myös siihen, että työttömien koulutus on alkanut vahvasti kiinnostaa.

$\mathrm{V}$ iimeisen vuosikymmenen aikana on entistä enemmän kiinnitetty huomiota laadulliseen kehittämiseen. On alettu pohtia, miten aikuisten koulutustarve tulisi selvittää, jotta koulutus palvelisi mahdollisimman hyvin sekä yksilöiden että organisaatioiden kehittymistä. On etsitty entistä tehokkaampia tapoja tukea aikuisten oppimista ja organisaatioiden kehittymistä. Erityisesti viime vuosina on alettu tutkia koulutuksen vaikuttavuutta, sen hyötyä koulutettavien, organisaatioiden ja yhteiskunnan kannalta.

Nykyään on olemassa jo varsin runsaasti tietoa siitä, miten aikuisia pitäisi kouluttaa, jotta koulutus olisi hyödyllistä. Ongelma on lähinnä siinä, että vain harvalla henkilöstö- ja täydennyskoulutusta suunnittelevalla on riittävä koulutus tehtäväänsä. Monet suunnittelijat tuntevat koulutuksen sisältöjä ja koulutettavien toimintaympäristön, mutta aikuisten oppimisprosessi on vieras. Toisaalta taas monilla aikuiskoulutuksen periaatteiden tuntijalla ei ole tarvittavaa sisällön tuntemusta.

Nykyistä ammatillista täydennyskoulutusta voidaan kritisoida monella tavalla. Esimerkiksi koulutuksen kesto on tärkeä kysymys. Lyhytkursseilla pyritään saamaan aikaan tuloksia, jotka edellyttäisivät monien kuukausien, jopa vuosien kouluttautumista. Työpaikan ihmissuhteet, johtamistaito tai työyhteisön kehittäminen ovat tyypillisiä aiheita, joiden oppiminen edellyttää useampivuotista koulutusta. Lyhytkurssitoiminta voi parhaimmillaan välittää uutta tietoa ja herättää tilapäistä kehittämishalua. Sen avulla voidaan vahvistaa myös osanottajien itseluottamusta kehittämällä jo olemassa olevaa ammattitaitoa.

Koulutusta annetaan usein irrallaan organisaation kehittämistarpeista. Jos vain yksi työntekijä yhteisöstä koulutetaan uuteen asiaan, ei voida odottaa muutoksia koko organisaation toiminnas- 
sa. Henkilöstön kehittäminen tulisikin nähdä entistä useammin osana koko organisaation kehittämisstrategiaa.

Yritysten oman henkilöstökoulutuksen suunnitteluun osallistuvat eivät aina ole perillä koko yrityksen kehittämistarpeista. Onnistunut koulutuksen suunnittelu edellyttää yrityksen johdon vahvaa panosta. Henkilöstön kehittäminen onkin yksi vaikuttavimmista johtamisen välineistä. Koulutuksen suunnittelusta vastaavien olisi toimittava kiinteässä yhteistyössä yrityksen johdon kanssa.

Henkilöstön koulutuksessa tyydytään yleensä konkreettien ammattivalmiuksien kehittämiseen.

Usein olisi kuitenkin hyödyllistä tarjota myös yleisempää teoriatietoa, joka auttaa ymmärtämään omaa työtä laajemmin ja arvioimaan työn yhteyksiä vaikkapa luonnon saastumiseen tai työntekijöiden työnsuojeluun.

S uomessa aikuiskoulutukseen on olemassa hy$\checkmark$ vät ulkoiset puitteet. Meillä on paljon tietoa siitä, miten koulutus tulisi järjestää. Mutta laadullisessa puolessa on vielä parannettavaa, varsinkin koulutuksen sisällöissä ja toteuttamistavoissa. Tämä vuosikymmen voitaisiinkin julistaa aikuiskoulutuksen laadun kehittämisen vuosikymmeneksi. Nopein tie entistä korkeatasoisempaan aikuiskoulutukseen on koulutuksen suunnittelijoiden ja kouluttajien ammattitaidon lisääminen.

\section{Kauko Hämäläinen}

